\title{
MUTUAL INTERDEPENDENCY BETWEEN CHINA, INDIA AND NEPAL
}

\author{
Gunja Kathet ${ }^{*}$
}

\begin{abstract}
Due to geographical proximity and historically long multi-faceted linkages between China, India and Nepal their foreign policy with each other is not distinctly independent but is mutually interdependent. This paper argues that Nepal's foreign policy has always prioritized maintaining balanced relation with these two nations for safeguarding its national interests, integrity and independence. While doing so it will also shed light upon how Nepal has age old and deep rooted relations between both China and India whereupon Nepal-China and Nepal-India relations have evolved through different circumstances, stages and periods till date.
\end{abstract}

Keywords: Buffer, Confluence, Interdependency, Sociocultural, Trilateral

Nepal has always been a place of confluence for the two great cultures that flourished in the north and south of the Himalayas. The cultures of Nepal have been influenced by both the Indian culture and the Chinese especially the Tibetan culture. Nepal is a place where the two great cultures (Indian and Tibetan) that flourished in the region, comes together and coexists. Nepal and India have a very intimate relationship with each other. The two nations have very strong sociocultural bonds with each other, that has been enhanced by various factors namely religion, language and cultural traditions. The influence of the Indian culture and tradition can be seen and felt in various aspects of the Nepalese society. Religion has been a major linking factor between India and Nepal. The two major religions of Nepal Buddhism and Hinduism both have their origins in India. Nepal was the last Hindu Kingdom of the world until the fall of the monarchy in 2008, thus, in Nepal 81.3 percent of the population follow Hinduism. Hence, with a large Hindu following in Nepal, the various Hindu religious sites in India have played a big role in strengthening the socio-cultural ties between the two nations, as large number of pilgrims visits these sites in India every year.

Language is also another factor that links the two nations. The two nations share a variety of common languages like Hindi, Nepali, Bhojpuri, Avadhi, etc. which are spoken in different parts of both the nations. The official languages of the two nations which are Nepali and Hindi both have their roots in Sanskrit and both of the languages use the Devnagari script; "The open border between the two nations, symbolizes a deep sociocultural, emotional and economic inter-linkages between the people of the two sides" (Baral 13). The open border has allowed an unrestricted movement of the people into each side, thus there is a large number of migration into either side that has given birth to the diaspora communities of each country into the other. China seeing the Indian influence in the cultural sectors of Nepal, has now began to set up various Chinese cultural and language institute in different parts of Nepal. Zhou Yongkang in his 5 point proposal.

* Lecturer of English, Dillibazar Kanya Multiple Campus, TU, Nepal 
mentioned, that China would also engage with Nepal on certain less tangible aspects such as cultural and educational exchanges which would boost the people to people exchanges between the two nations ( Dahal 8). The Chinese have understood that the major factor that links India and Nepal is the language. In Nepal majority of the population are familiar with the Hindi language and also the Nepalese have access to a large number of television channels based in Hindi, which helps in spreading the knowledge of the Hindi language to the Nepalese people. Hence, to counter this influential factor of India in Nepal, China has set up various China Study Centres (CSCs) in various parts of Nepal. These China 10 Study Centres serve the purpose of promoting cultural and language exchanges between Nepal and China and are entirely funded by China. There are "ten local branches of the CSC besides the main central organization of CSC-Nepal in Kathmandu and there are about 33 CSCs that has been set up in the southern region of Nepal that borders India" (Baral 19).

Lok Raj Baral in Building the Bridge: India, China and Nepal(2016) argues that Nepal-China and Nepal-India relations have multitude linkages ranging from social, cultural, religious, geopolitical, and economic to diplomatic affairs. One belt one road is the milestone point for both Nepal and China of the 21 st century. There is more mutual trust and less or no disagreement in Nepal-China relations but there are less mutual trust and more disputes in Nepal-India relation:

There were ups and downs in Nepal-India relations in the past. At present, Nepal and India have very volatile and unstable relations, sometimes friendly and sometimes hostile, although Nepal always wants to have stable relations with India. There has been a lack of confidence and mutual trust to one another in Nepal. India relations after declaration of new constitution in 2015 that followed an unannounced trade embargo from Indian side. (Dahal 56)

Nepalese nationals' sentiment towards India was not good thereafter and people thought that India has its own interests in Nepal's internal issues. So, in order to build good relations between Nepal and India, Indian government should respect Nepal's sovereignty and independence and all business dealings must be based on equal status.

The greatest challenges in Nepal's foreign relations, at the present context, are: to build good mutual trust and win confidence from its neighbors; to maintain balanced and equal distance in relations with China and India; to make China and India join hands together for broader, deeper and stronger economic ties for equal mutual benefits of all. China and India are ready in restructuring foreign affairs with New Nepal in the changed perspective from a newer dimension. PramodJaiswal in Nepal Between India and China: Demystifying Big Powers Interplay, opines:

Economic growth, development and prosperity must take the central stage while redefining and revising the one to one and triangular relation between Nepal, China and India, Foreign Relation keeping respect for each other's national sovereignty, integrity and independence intact. (10)

Nepal's foreign relation with China and India must be directed towards regional peace, integrity and prosperity.In practice, Nepal has observed friendly and cordial relations with China while the relation with India has been both friendly and hostile.

Nepal is firmly committed to "One China Policy"(Dahal 57) and signed OBOR (One Belt One Road) and respects India's national independence and integrity. China has shown respect to 
Nepal's sovereignty and has not interfered in Nepal's internal issues while India has been seen trying to influence Nepal's internal politics:

OBOR is an ambitious Mega project introduced by Chinese President Xi Jinping with the aim of promoting connectivity and cooperation among the countries in the region and beyond. President Xi, on his visit to Central Asia in September and South East Asia in October, 2013, raised the idea of jointly building the Silk Road Economic Belt and 21 Century Maritime Silk Road. Both together became known as the OBOR. It has now been named BRI (Belt and Road Initiatives) which is taken as a development approach for materializing the partnership of countries in development for common destiny and shared future. (Baral 11)

Nepal, China and India must reach a new consensus to re-build strong Foreign Relations and economic ties for mutual benefit. Geographically, Nepal sits uneasily hemmed between China and India. Caustically, and appropriately, analysts have called Nepal as the yam between two boulders.

Circumscription by two mega-states and their strategic ambitions have resultedin Nepal's vulnerability in defining its foreign policy options. Although, Nepal has sought tomanoeuvre its diplomatic strategy to indicate cultivation of good ties with both countries, its record has been uneven with the effect that Nepal has neither been able to benefit from the growth of its two neighbors, nor has it been able to devise mechanisms to resist the intervention of these countries into its internal affairs. Nepal acts as a buffer between India and China. Both these countries, which have already gone once to war in 1962 and have a history of border tensions, wish to use Nepal as a strategic entry point. The strategic angle to the relationship is embedded through allusions to religious-cultural ties. With both countries being predominantly Hindu -Nepal is accorded the status of 'younger sister'. Similarly, the Hindu right often makes allusions to Akhand Bharat which incorporates the whole of South Asia:

This sub-continental paternalism causes great anxieties in the region, the nature of which is only overtly strategic, but more deeply existential for Nepal. The effort to culturally link Nepal's identity to India renders Nepal with an identity void of its own. In the past few years, Nepal's desire to feel 'different' and not be treated like a 'cultural extension' of India has become more pronounced. (Muni 54)

However, the links between the two countries are not only cultural or strategic. Across the 1700 kms of border line people, communities, goods move across borders adding multiple dimensions to bilateral relations which cannot be captured within the grand narrative of strategic and cultural ties. India, being the bigger and resource-wise better equipped state, offers more opportunities to Nepalese on the border which naturally raises disturbing questions about the public welfare dimension of the Nepali state, and undercuts its sovereignty. Any understanding of the relationship between India and Nepal must, therefore, take cognizance of these factors. The heightened sense of identity theft that Nepal sees emanating from India is pre-disposed to the strategic, cultural and quotidian experiences of Nepal vis-à- vis India.

The prejudiced Indian stand towards Nepal dates back to the treaty of 1950. The Treaty of Peace and Friendship, as it was called, was the first of India-Nepaltreaties that founded the bilateral relationship on unequal footing. The Treaty, signed between Rana rulers of Nepal, set the basic 
principles of bilateral relationship by awarding substantial leverage to India in Nepal. For instance, Article 2 of the Treaty states that the two governments hereby undertake to inform each other of any serious fiction or misunderstanding with any neighboring state likely to cause any breach in the friendly relations subsisting between the two governments. This clause leaves a big vacuum for interpretations of the clause "breach of friendly relations" (Dahal 50) and has further granted India the pretext to question Nepal's dealings with any neighboring state, most importantly China. In 1961, China and Nepalagreed to construct a 104-kilometer road from Kathmandu to Kodari on the China-Nepal border:

Against this, Indian Prime Minister Jawaharlal Nehru expressed strong reservations stating that 'India's security interests would be adverselyaffected by the road'. He asserted that Nepal's failure to consult with India on the matter was a flagrant violation of the treaty of 1950, both in letter and spirit. One could argue here that Nehru's concerns about India's security were genuine, but in exchange he paid no attention to the developmental needs of Nepal. (Baral 15)

Such a stance otherwise too differs from what Nehru himself preached to the world when he stated that foreign policies of Asia and Africa ought to be governed by their needs of development, rather than needs of war. A road connecting Nepal to Tibet is essential to provide the much needed impetus to trade and commerce.

India-China friendship that existed in the 1950s, captured in the rhetoric of Hindi-Cheenibhaibhai (India and China are brothers) eroded in the 1960s with the Sino-Indian War of 1962, where Nepal cautiously adhered to the principle of neutrality. Nepal witnessed hardening of the Indian stand vis-à-vis Nepal's relations with China. In Nepal, Mahendra succeeded his father Tribhuwan to the crown who sought to maximise Nepal's international leverage by diversifying Nepal's foreign policy by establishing bilateral relations with countries outside the region. Domestically, the new King strengthened his power imprisoning the elected Prime Minister, B.P. Koirala is known for his closeness to India. This greatly circumcised the Indian influence in Nepali polity. King Mahendra hedged against India by drawing closer to China concluding a boundary treaty with China and also signing anagreement for building Kodari highway linking Nepal to Tibet. However, he dismissed any apprehensions of Chinese entry into Nepal by stating "Communism doesn't come in a taxi"(qtd. in Baral 16). India, while keeping concerns for democracy rhetorically alive, soon came to understand that it would have to cultivate, rather than antagonise, King Mahendra. Soon, India signed four aid agreements with KingMahendra's regime.

China-Nepal relationship is relatively new. The two are geographically separatedby a 1,415-km Himalayan border. Despite many cultural semblances of the people of Upper Himalayan region in Nepal and Tibet, the interaction is limiteddue to the Himalayan segregation and is not as intense as Indo-Nepal interactions. As China seeks to translate its economic clout into major geopolitical advantage in Asia, Nepal makes it to its priority list. Of the four Ts that dominate China's global engagement -Tibet, Taiwan, Tiananmen and Trade; Nepal fits into China's strategic calculus due to its proximity to Tibet. China was least interested in Nepal till 1950s. The Chinese occupation of Tibetin 1950 significantly increased Nepal's strategic importance for China. The establishment of diplomatic relations between the two countries in 1955 opened up whole new vistas for the friendship and cooperation between China and Nepal. Nepal-China relations are based on the Five Principles, or Panchasheel, according to which China will not intervene in Nepal's domestic 
politics and Nepal will respect China's sovereignty and territorial integrity with respect to Tibet and Taiwan.

To sum up, due to geographical proximity and historically long multi-faceted linkages between China, India and Nepal their foreign policy with each other is not distinctly independent but is mutually interdependent. This paper argues that Nepal's foreign policy has always prioritized maintaining balanced relation with these two nations for safeguarding its national interests, integrity and independence. While doing so it will also shed light upon how Nepal has age old and deep rooted relations between both China and India whereupon Nepal-China and Nepal-India relations have evolved through different circumstances, stages and periods till date.

\section{Works Cited}

Baral, BhimNath. Nepal-China-India: Prospects and Challenges of Trilateralism. Journal of Political Science. PN Campus: Volume XIX, 2016.

Baral, Lok Raj. Building the Bridge: India, China and Nepal. In India-China-Nepal: Decoding Trilateralism. Eds:PramodJaiswal and GeetaKochhar. New Delhi: G.B. Books, 2016.

Dahal, Girdhari. Foreign Relation of Nepal with China and India. Journal of Political Science, Volume XVIII, 2018.

Jaiswal, Pramod. Nepal Between India and China: Demystifying Big Powers Interplay, In IndiaChinaNepal-Decoding Trilateralism. Eds: by PramodJaiswal and GeetaKochhar. New Delhi: G.B. Books, 2016.

Muni, S.D. Trilateral Engagement Between India China and Nepal, In India-China-Nepal: Decoding Trilateralism. Eds: PramodJaiswal and GeetaKochhar. New Delhi: G.B. Books, 2016.

Sapkota, Rupak. Nepal China Relation Beyond the Traditional Approach, in Souvenir: Celebrating Nepal China 60th year of Diplomatic Relations.Eds: PannaKajiAmatya, Kathmandu: Institute of Foreign Affairs, Nepal, 2016. 